\title{
Carbon storage of headwater riparian zones in an agricultural landscape
}

Richard D Rheinhardt ${ }^{1 *}$, Mark M Brinson', Gregory F Meyer ${ }^{2}$ and Kevin H Miller 2,3,4

\begin{abstract}
Background: In agricultural regions, streamside forests have been reduced in age and extent, or removed entirely to maximize arable cropland. Restoring and reforesting such riparian zones to mature forest, particularly along headwater streams (which constitute $90 \%$ of stream network length) would both increase carbon storage and improve water quality. Age and management-related cover/condition classes of headwater stream networks can be used to rapidly inventory carbon storage and sequestration potential if carbon storage capacity of conditions classes and their relative distribution on the landscape are known.

Results: Based on the distribution of riparian zone cover/condition classes in sampled headwater reaches, current and potential carbon storage was extrapolated to the remainder of the North Carolina Coastal Plain stream network. Carbon stored in headwater riparian reaches is only about $40 \%$ of its potential capacity, based on 242 $\mathrm{MgC} / \mathrm{ha}$ stored in sampled mature riparian forest (forest $>50$ y old). The carbon deficit along $57,700 \mathrm{~km}$ headwater Coastal Plain streams is equivalent to about 25TgC in 30-m-wide riparian buffer zones and $50 \mathrm{TgC}$ in 60-m-wide buffer zones.

Conclusions: Estimating carbon storage in recognizable age-and cover-related condition classes provides a rapid way to better inventory current carbon storage, estimate storage capacity, and calculate the potential for additional storage. In light of the particular importance of buffer zones in headwater reaches in agricultural landscapes in ameliorating nutrient and sediment input to streams, encouraging the restoration of riparian zones to mature forest along headwater reaches worldwide has the potential to not only improve water quality, but also simultaneously reduce atmospheric $\mathrm{CO}_{2}$.
\end{abstract}

Keywords: carbon storage capacity, condition, riparian buffer

\section{Background}

A significant amount of global carbon can be sequestered in forests [1-3] and especially in forest soils [4,5]. This is particularly true for soils in wetlands where decomposition is slower [6,7]. In agricultural regions of the world, many forests along headwater streams, generally first to fourth order (sensu [8]), have been completely removed or severely reduced in extent in order to maximize arable cropland. The alterations in buffer zones resulting from forest removal and conversion to agriculture have led to reductions in ecosystem services, including a decline in water quality due to increased soil erosion and a reduced capacity for nutrient uptake and

\footnotetext{
* Correspondence: rheinhardtr@ecu.edu

'Department of Biology, East Carolina University, Mail Stop 551, Greenville, North Carolina, 27858, USA

Full list of author information is available at the end of the article
}

denitrification $[9,10]$, a reduction in habitat quality [11], a reduction in stream particulate organic carbon [12], and an increase in atmospheric $\mathrm{CO}_{2}[13,14]$.

It is well known that the aboveground carbon pools of forests gain biomass as they age [15-17] as do forest soils $[18,19,5]$. However, there is still a paucity of field data for estimating the amount of carbon sequestered as riparian forests age or on how carbon is segregated among various biomass compartments: living vs. detrital, aboveground vs. belowground, or among strata. In order to adequately estimate the potential effects of riparian reforestation on the amount and rate of carbon storage, it would be useful to know to how much carbon is stored in various types of vegetation cover types, in forests of various ages, and in soils as riparian forests develop. Data from headwater riparian forests would be particularly useful because restoration and regeneration 
of riparian forest not only sequesters atmospheric carbon, but also improves water quality.

\section{Results and Discussion}

The carbon content of riparian zone cover/condition types ranged from 17.9 MgC/ha for Annual Rowcrop agriculture to $241.7 \mathrm{MgC} /$ ha for Mature Forest (> $50 \mathrm{y}$ old) (Table 1) [20,21]. Total carbon content of Mature Forest is 7-13 times that of non-forest condition types (Perennial Herb, Shrub/Sapling, and Annual Rowcrop). The highest proportion of carbon is concentrated in living trees, with 2.6 times as much in Mature Forest than in Regenerating Forest (5-25 y old), while the highest concentration of detrital-based carbon is concentrated in forest soil. These values do not include the carbon content of roots, which were not measured, or carbon content of soil $>10 \mathrm{~cm}$ in depth. Roots would be expected to provide $10-15 \%$ additional carbon [22] and soil organic carbon to $1 \mathrm{~m}$ depth would be at least twice the amount recorded [23].

The living and detrital pools of mature Coastal Plain riparian forests are similar in magnitude to other mature temperate forests studied. The $203 \mathrm{MgC} /$ ha for aboveground biomass in Mature Forest is within the range exhibited by a 60-100 y old Pinus strobus-dominated forest in Rhode Island, USA (185-301 MgC/ha) [24]. Average annual rate of ecosystem carbon accumulation in the sampled riparian forests was approximately 2.6 $\mathrm{MgC} / \mathrm{ha} \mathrm{y}^{-1}$ over $80 \mathrm{y}$, which was a bit higher than other temperate (upland) hardwood forest ecosystems (1.3-2.1 $\mathrm{MgC}$ ha $\left.^{-1}\right)$ [24], but reasonable considering the riparian forests in this study are seasonally saturated wetlands in a Humid Subtropical climate.

Once carbon values were established for condition types, carbon status was extrapolated over the entire Coastal Plain headwater stream network based on the distribution of condition types along the sampled networks (Table 2) [25,22]. Because the ratio of headwater network length to watershed size in the sampled watersheds was 1.008, the total length of headwater streams in the Coastal Plain was estimated to be about $57,227 \mathrm{~km}$.

An average of $95 \mathrm{MgC} / \mathrm{ha}$ occurred along the 60-mwide riparian zone of the three sampled Coastal Plain stream networks. This is far less than a potential 242 $\mathrm{MgC} / \mathrm{ha}$ that would be stored if the entire riparian zone were Mature Forest. Assuming that the three sampled stream networks represent all other rural, headwater, stream networks in Coastal Plain North Carolina, then headwater riparian zones in the Coastal Plain currently store 16.5 to $32.8 \mathrm{TgC}$, depending on whether the riparian zone is defined as being $30-\mathrm{m}$ wide $(16.5 \mathrm{TgC})$ or $60-\mathrm{m}$ wide $(32.5 \mathrm{TgC})$. These carbon amounts are about $40 \%$ of what is possible (Table 2) $[25,22]$ and represent a shortfall of 25.0 to $50.5 \mathrm{TgC}$ (depending on riparian zone width) based on the carbon storage capacity of Mature Forest. This means that if buffer zones of Coastal Plain stream networks are similar, on average, to the condition of sampled networks, then there is potential for storing an additional 25 to $50 \mathrm{TgC}$ (from 30- and 60-m-wide buffers, respectively). Fifty $\mathrm{TgC}$ is equivalent to the average annual carbon emissions of about 36,000 homes or 16,000 passenger vehicles (see [26] for other equivalencies). Focusing carbon offsets on riparian zones, particularly in agricultural landscapes, has the advantage of improving water quality of rivers and the estuaries they feed.

Studies that finely compartmentalize living and detrital carbon pools are rare. Even fewer studies provide a chronosequence to depict change in carbon storage among compartments through time. This study is the first to define riparian forest carbon storage by broad cover/condition types related to a forest development sequence and then extrapolate the relative areal extent

Table 1 Mean stored carbon (MgC/ha) of living and detrital components for condition types in headwater riparian zones

\begin{tabular}{|c|c|c|c|c|c|c|c|c|c|c|c|c|c|}
\hline $\begin{array}{l}\text { Condition type } \\
\text { (n) }\end{array}$ & Tree & Shrub & Sapling & Herb & $\begin{array}{l}\text { Woody } \\
\text { Seedling }\end{array}$ & Vine & Litter & Snag & $\begin{array}{l}\text { Large Down } \\
\text { Wood }\end{array}$ & Soil & $\begin{array}{l}\text { Total } \\
\text { Live }\end{array}$ & $\begin{array}{c}\text { Total } \\
\text { Detrital }\end{array}$ & $\begin{array}{c}\text { Total Carbon } \\
\text { Stored }\end{array}$ \\
\hline Mature Forest (5) & 155.7 & 0.1 & 0.2 & 0.1 & - & 0.2 & 34.4 & 8.3 & 3.6 & 39.2 & 156.3 & 85.4 & 241.7 \\
\hline Young Forest (5) & 59.4 & 0.0 & 0.3 & 0.1 & 0.1 & 0.2 & 20.6 & 2.4 & 11.9 & 33.4 & 60.1 & 68.2 & 128.4 \\
\hline $\begin{array}{l}\text { Regenerating } \\
\text { Forest (6) }\end{array}$ & 59.2 & 0.1 & 0.4 & 1.3 & 0.1 & 0.2 & 6.8 & 1.1 & 4.5 & 28.6 & 61.3 & 41.0 & 102.3 \\
\hline $\begin{array}{c}\text { Recently Clearcut } \\
\text { (3) }\end{array}$ & 1.2 & 0.0 & 0.1 & 0.6 & 0.2 & 0.1 & 15.5 & 4.0 & 19.3 & 41.4 & 2.2 & 80.3 & 82.5 \\
\hline $\begin{array}{c}\text { Perennial Herb } \\
\text { (3) }\end{array}$ & - & 0.2 & 0.2 & 3.9 & 0.4 & 1.3 & 0.7 & - & - & 29.1 & 6.1 & 29.8 & 35.8 \\
\hline Shrub/Sapling (2) & - & - & - & 3.6 & - & 0.0 & 4.3 & - & - & 21.0 & 3.6 & 25.3 & 28.9 \\
\hline $\begin{array}{c}\text { Annual Rowcrop } \\
{[21]}\end{array}$ & - & - & - & 0.8 & - & - & 0.8 & - & - & 16.3 & 0.8 & 17.1 & 17.9 \\
\hline
\end{tabular}

Mature Forest (> 50 y old), Young Forest (26-50 y), Regenerating Forest (5-25 y), Recently Clearcut (0-5 y). Data derived from [20]. 
Table 2 Carbon stored in headwater riparian reaches of sampled riparian zones and extrapolated to the entire Coastal Plain network

\begin{tabular}{|c|c|c|c|c|c|c|c|c|}
\hline $\begin{array}{l}\text { Location }(n=\text { no. } \\
\text { of reaches) }\end{array}$ & $\begin{array}{l}\text { Watershed } \\
\text { size }\left(\mathrm{km}^{2}\right)\end{array}$ & $\begin{array}{c}\text { Stream } \\
\text { network } \\
\text { length }(\mathrm{km})\end{array}$ & $\begin{array}{c}\mathrm{MgC} / \mathrm{ha} \\
\text { (30-m- } \\
\text { wide } \\
\text { zone) }\end{array}$ & $\begin{array}{c}\text { MgC/ha } \\
\text { (60-m- } \\
\text { wide } \\
\text { zone) }\end{array}$ & $\begin{array}{l}\mathrm{MgC} / \mathrm{km} \text { stream } \\
\text { length (30-m- } \\
\text { wide zone) }\end{array}$ & $\begin{array}{l}\mathrm{MgC} / \mathrm{km} \text { stream } \\
\text { length (60-m- } \\
\text { wide zone) }\end{array}$ & $\begin{array}{l}\text { Total MgC } \\
\text { stored in (30- } \\
\text { m-wide zone) }\end{array}$ & $\begin{array}{c}\text { Total } \mathrm{MgC} \\
\text { stored in (60- } \\
\text { m-wide zone) }\end{array}$ \\
\hline Cow Swamp (40) & 44.5 & 47.5 & 94.2 & 92.3 & 283 & 554 & 13,427 & 26,299 \\
\hline Crisp Creek (37) & 45.9 & 41.2 & 84.0 & 87.0 & 252 & 522 & 10,380 & 21,514 \\
\hline Lumber (66) & 73.7 & 74.8 & 104.4 & 100.5 & 313 & 603 & 23,415 & 45,070 \\
\hline $\begin{array}{l}\text { Current condition } \\
\text { of Coastal Plain } \\
\text { riparian zones }\end{array}$ & 56,772 & 57,227 & 96.3 & 94.7 & 289 & 568 & $16,529,285$ & $32,512,359$ \\
\hline $\begin{array}{l}\text { Potential condition } \\
\text { of Coastal Plain } \\
\text { riparian zones }\end{array}$ & 56,772 & 57,227 & 241.7 & 241.7 & 0.725 & 1.450 & $41,495,029$ & $82,990,058$ \\
\hline Difference & & & & & & & $24,965,744$ & $50,477,700$ \\
\hline
\end{tabular}

Carbon is estimated to be 0.5 times organic matter [25]. Data for Coastal Plain riparian zones based on the weighted average of the three sampled watersheds. Potential carbon storage based on carbon estimated in Mature Forest. Current and potential carbon values of Coastal Plain riparian zones based on extrapolation from sampled networks. Riparian zone widths: 30-m-wide zone includes the 0-15 m bands on both sides of stream; the 60 -m-wide zone includes the 0-30 $\mathrm{m}$ bands on both sides of stream. "Difference" represents the amount of additional carbon that could potentially be stored in Coastal Plain headwater networks. Total carbon pool would be about 10-15\% more than indicated values if large roots (not sampled) were also included [23].

of those condition types to a larger region to estimate the potential gain in carbon storage that could accrue following full reforestation to mature forest.

\section{Conclusions}

Headwater riparian zones are particularly important hotspots for influencing water quality because $90 \%$ of the interface between uplands and aquatic systems occurs in headwater reaches. This makes headwater reaches the major recipient of nonpoint source pollution in agricultural landscapes. However, most headwater reaches in agricultural landscapes are poorly buffered, i.e., either buffers are narrow and/or remnant buffers represent young developmental stages. This situation likely arose from efforts to maximize arable cropland and manage streamside forests as woodlots. Poor riparian buffers have exacerbated water quality problems because the reduction in living and detrital biomass associated with deteriorated buffers has allowed for increased soil erosion and nutrient input in combination with reductions in nutrient uptake and denitrification. By measuring organic matter stored in various condition classes found along streams and randomly sampling headwater reaches to identify the relative distribution of those condition classes along streams, this study found that riparian buffer zones of headwater streams in Coastal Plain North Carolina store only $40 \%$ of the carbon they could potentially store if mature forest buffered all streams. Many headwater streams in the agricultural landscapes worldwide are also poorly buffered. Encouraging the development of older-aged forests, particularly mature forest, in headwater reaches of agricultural regions has the potential to improve ecosystem services like water quality and habitat quality, while simultaneously sequestering a huge amount of atmospheric carbon. Thus, restoration of riparian forest buffer zones in agricultural landscapes, particularly in headwater reaches, should become a priority worldwide.

\section{Methods}

A space-for-time approach was used to obtain data on storage of carbon as riparian forests develop from agricultural fields to shrub/saplings to mature forest. Riparian ecosystems in Coastal Plain North Carolina are naturally vegetated by forest, and so mature forest is the endpoint in vegetation development. However, riparian zones along most headwater portions of stream networks have been converted to other uses (mostly agriculture) and are thus in varying stages of development. After extensive surveys of headwater riparian zones, it was found that riparian vegetation could be partitioned into one of eight easily-recognizable age and coverrelated condition types, which correspond to a chronosequence from agriculture to mature forest: (1) Annual Rowcrop (corn, soybean, cotton), (2) Perennial Herb (usually fallow field of grasses and perennial forbs), (3) Shrub/Sapling, (4) Recently Clearcut Forest (< 5 y since last clearcut), (5) Regenerating Forest (5-25 y old), (6) Young Forest (26-50 y old), and (7) Mature Forest (> 50 $\mathrm{y}$ old). Biomass was determined for these condition types, by biomass category (roots excluded), in 30-m long by $10-\mathrm{m}$ wide belt transects along 18 stream reaches in agricultural, Coastal Plain North Carolina. Each sampled reach consisted of one to several condition classes (Figure 1). Detailed methods for determining biomass by condition type, further partitioned by living and detrital biomass categories, are explained in companion studies [20,27]. Assuming that dry plant biomass 


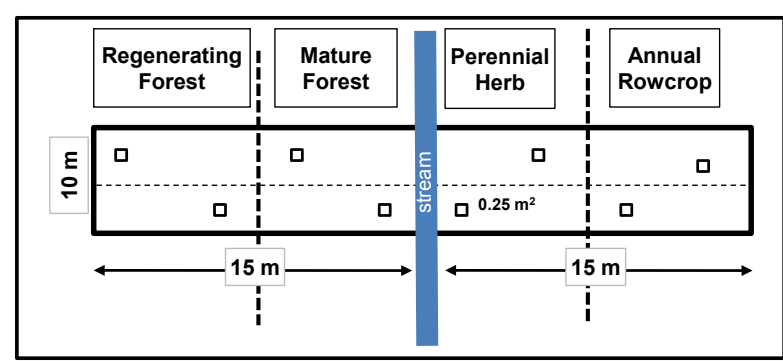

Figure 1 Layout of $10 \times 30 \mathrm{~m}$ belt transects for sampling biomass of riparian condition types. Locations of imbedded 0.25 m quadrats are small squares $(n=6)$ within belt transects. Diagram illustrates a hypothetical juxtaposition of four condition types.

and soil organic matter is about $50 \%$ organic carbon $[28,25]$, biomass was converted to carbon content for each of the sampled compartments.

After carbon was quantified for each condition class, 100 -m long reaches $(n=143)$ were randomly chosen in three rural Coastal Plain stream networks, all embedded in agricultural drainage basins, ranging in size from 44.5 to $73.7 \mathrm{~km}^{2}$. Sampled reaches constituted about $10 \%$ of stream network length [29]. However, before defining the stream network, it was necessary to ensure that all intermittent streams in the network were included. This was a challenge because most headward, first order streams are often not even depicted as streams on United States Geologic Survey (USGS) 1:24 K topographic maps and associated digital files, even some that flow year-round during wet years. Considering that many headwater streams are missing on USGS maps, additional headward portions of intermittent, groundwaterdriven reaches in the three sampled stream networks were manually mapped, using hydrogeomorphic criteria. Detailed methods of this mapping exercise are provided in [29].

After mapping condition classes along a 100-m reach, the cover of condition classes were estimated for each side of the stream separately with respect to two riparian zone bands, extending perpendicular from the stream edge: a 0-15 m band and a $15-30 \mathrm{~m}$ band on each side [20]. Sometimes more than one condition type occurred within one of the two riparian bands. When this occurred, the types were apportioned to the band in approximate proportion to their relative cover. Condition-type data for each 100-m reach within a band were then converted to total stored carbon. Carbon storage data from both sides of the stream reach were combined: inner bands combined to provide carbon storage data for a 30-m-wide zone, and all data combined to obtain data for a 60-m-wide zone. Since the reaches were $100 \mathrm{~m}$ long, the data for the two riparian zones were for $1 / 3$ ha (for the 30 -m-wide zone) and $2 / 3$ ha (for the 60-m-wide zone).

Assuming that the three sampled headwater networks represented the condition of all Coastal Plain riparian zones, the carbon content of the sampled riparian zones was extrapolated to the entire North Carolina Coastal Plain headwater network. Potential carbon content was then estimated by calculating the amount of carbon that could be stored if all riparian zones were allowed to regenerate to mature forest. Thus, the difference between potential and current carbon content of riparian zones represents the amount of additional carbon that could potentially be stored in Coastal Plain riparian zones.

The main assumption of this approach is that the sampled stream networks represent the condition of the entire Coastal Plain headwater network. Even though the sampled watersheds had been identified $a$ priori by the state of North Carolina as being watersheds with impaired water quality (sensu Clean Water Act, Section 303d), based on the authors' considerable field experience in the Coastal Plain, it did not appear that riparian zone condition in the sampled stream networks differed substantially from other headwater stream networks.

The main limitation of this study is that the sampled watersheds represent only the rural (agricultural) and headwater portions of the Coastal Plain, i.e., urban portions of networks and portions of networks larger than $4^{\text {th }}$ order were not included in this analysis. However, the headwater reaches of mapped $1^{\text {st }}-4^{\text {th }}$ order steams represent $>90 \%$ of all stream length in Coastal Plain North Carolina (Rheinhardt, unpublished data), most higher order stream reaches $\left(>4^{\text {th }}\right.$ order) are adequately buffered by forest (although not everywhere by mature forest), and the proportion of urban stream length is rather small in relation to rural stream length.

Hydrologic conditions are known to affect rates of carbon sequestration. Net primary production has been found to significantly differ between wet sites (permanently to semi-permanently saturated) and drier sites (seasonally saturated to upland sites), but not between seasonally saturated and upland sites [30]. Hydrologic conditions of the riparian zones of this study ranged from seasonally saturated to upland and so no differences were expected in sequestration rates across the moisture gradient, i.e., carbon storage in similarly-aged forest stands would not be expected to significantly differ between the wetland portion of the riparian zone and the upland portion of the zone. Further, any differences in carbon sequestration that could be attributable to soil moisture differences would be incorporated in the species-specific allometric and regression equations that were used to estimate biomass, since each species 
tends to be concentrated along certain portions of the moisture gradient from wetland to upland.

\section{List of abbreviations}

USEPA: United States Environmental Protection Agency; NCAS: North Carolina Agricultural Statistics

\section{Acknowledgements}

Jane Almon, Mike Schlegel, Melissa Ruiz, and Amber Coleman led teams that assessed all the randomly chosen reaches and provided field data in a timely manner. Chris Bason and Emma Hardison helped assess a sub-sample of the reaches. The manuscript also benefited from the input of three anonymous reviewers. The research was supported by a grant from the North Carolina Ecosystem Enhancement Program provided by the U.S. Environmental Protection Agency (USEPA) state grant program. Progress on this project benefited from our participation with the Atlantic Slope Consortium, which received funding from USEPA's Science to Achieve Results (STAR) Estuarine and Great Lakes (EaGLe) program through Penn State University, USEPA Agreement (R-82868401). Although the research described in this article has been funded wholly or in part by the USEPA, it has not been subjected to the Agency's policy review and therefore does not necessarily reflect the views of the Agency and no official endorsement should be inferred.

\section{Author details}

'Department of Biology, East Carolina University, Mail Stop 551, Greenville, North Carolina, 27858, USA. ${ }^{2}$ Coastal Resources Management, East Carolina University, 379 Flanagan, Greenville, North Carolina, 27858, USA. ${ }^{3}$ North Carolina Department of Environment and Natural Resources, 1601 Mail Service Center, Raleigh, North Carolina, 27699, USA. ${ }^{4}$ Current address: Bureau of Land Management, Grand Staircase-Escalante National Monument, 669 South Highway 89A, Kanab, Utah, 84741, USA.

\section{Authors' contributions}

RR helped conceive the study, participated in study design, fieldwork and data analysis, and drafted the manuscript. MB helped conceive the study, participated in study design, and fieldwork. GM participated in field work, lab work, data entry and analysis, and GIS work. KM: participated fieldwork, lab work, data entry and analysis, and GIS work. All authors read and approved the final manuscript.

\section{Competing interests}

The authors declare that they have no competing interests.

Received: 18 August 2011 Accepted: 14 February 2012

Published: 14 February 2012

\section{References}

1. Dixon RK, Brown S, Houghton RA, Solomon AM, Trexler MC, Wisniewski J: Carbon pools and flux of global forest ecosystems. Science 1994, 263:185-190

2. Turner DP, Koerper GJ, Harmon ME, Lee JJ: A carbon budget for forests of the conterminous United States. Ecol Appl 1995, 5:421-436.

3. Canadell JG, Raupach MR: Managing forests for climate change mitigation. Science 2008, 320:1456[http://www.sciencemag.org/content/ 320/5882/1456.short]

4. Post WM, Emmanuel WR, Zinke PJ, Stangenberger AG: Soil carbon pools and world life zones. Nature 1982, 298:156-159.

5. Lal R: Global potential of soil carbon sequestration to mitigate the greenhouse effect. CRC Crit Rev Plant Sci 2003, 22:151-184.

6. Savage KE, Davidson EA: Interannual variation of soil respiration in two New England forests. Global Biogeochem Cycles 2001, 15:337-350.

7. Phillips SC, Varner RK, Frolking S, Munger JW, Bubie JL, Wofsy SC, Crill PM: Interannual, seasonal, and diel variation in soil respiration relative to ecosystem respiration at a wetland to upland slope at Harvard Forest. J Geophys Res 2010, 115:G02019.

8. Strahler AN: Quantitative analysis of watershed geomorphology. Eos (Washington DC) 1957, 8:913-920.
9. Lowrance R, Altier LS, Newbold JD, Schnabel RR, Groffman PM: Water quality functions of riparian forest buffers in Chesapeake Bay watersheds. Environ Manage 1997, 21:687-712, 8 others.

10. Naiman RJ, Decamps H: The ecology of interfaces: riparian zones. Annu Rev Ecol Syst 1997, 28:621-658.

11. Semlitsch RD, Bodie JR: Biological criteria for buffer zones around wetlands and riparian habitats for amphibians and reptiles. Conserv Biol 2003, 17:1219-1228.

12. Tank JL, Rosi-Marshall EJ, Griffiths NA, Entrekin SA, Stephen ML: A review of allochthonous organic matter dynamics and metabolism in streams. J North Am Benthol Soc 2010, 29:118-146.

13. Edwards NT, Ross-Todd BM: Soil carbon dynamics in a mixed deciduous forest following clear-cutting with and without residue removal. Soil Sci Soc Am J 1983, 47:1014-1021.

14. Schlamadinger B, Marland G: Net effect of forest harvest on $\mathrm{CO} 2$ emissions to the atmosphere: a sensitivity analysis on the influence of time. Tellus B Chem Phys Meteorol 1999, 51:314-325.

15. Odum EP: The strategy of ecosystem development. Science 1969, 164:262-270

16. Luyssaert $\mathrm{S}$, Schulze ED, Borner A, Knoh A, Hessenmoller D, Law BE, Ciais $P$, Grace J: Old-growth forests as global carbon sinks. Nature 2008, 455:213-215.

17. Alexandrov GA: Carbon stock growth in a forest stand: the power of age. Carbon Balance and Manag 2007, 2:4[http://www.cbmjournal.com/content/ $2 / 1 / 4]$.

18. Nakane K, Lee N: Simulation of soil carbon cycling and carbon balance following clear-cutting in a mid-temperate forest and contribution to the sink of atmospheric $\mathrm{CO}_{2}$. Vegetatio 1995, 121:147-156.

19. Post WM, Kwon KC: Soil carbon sequestration and land-use change: processes and potential. Glob Change Biol Bioenergy 2000, 6:317-327.

20. Rheinhardt RR, Brinson MM, Meyer G, Miller KH: Integrating forest biomass and distance from channel to develop an indicator of riparian condition., Accepted.

21. NCAS (North Carolina Agricultural Statistics): Crop statistics: county estimates, by crop. North Carolina Department of Agriculture and Consumer Services Raleigh, NC, USA; 2001.

22. Cairns MA, Brown SA, Helmer EH, Baumgardner GA: Root biomass allocation in the world's upland forests. Oecologia 1997, 111:1-11.

23. Jobbagy EG, Jackson RB: The vertical distribution of soil organic carbon and its relation to climate and vegetation. Ecol Appl 2000, 10:423-436.

24. Hooker TD, Compton JE: Forest ecosystem carbon and nitrogen accumulation during the first century after agricultural abandonment. Ecol Appl 2003, 13:299-313.

25. Pribyl D: A critical review of the conventional SOC to SOM conversion factor. Geoderma 2010, 156:75-83.

26. USEPA (U.S. Environmental Protection Agency): Greenhouse gas equivalencies calculator. 2010 [http://www.epa.gov/cleanenergy/energyresources/calculator.html\#results].

27. Brinson MM, Miller KH, Rheinhardt RD, Christian R, Meyer G, O'Neal J: Developing reference data to identify and calibrate indicators of riparian ecosystem condition in rural Coastal Plain landscapes in North Carolina. Report to the Ecosystem Enhancement Program, North Carolina Department of Environment and Natural Resources Raleigh, NC, USA; 2006 [http://www. nceep.net/pages/resources.htm\#papers].

28. Richter DD, Markewitz D, Wells, Allen HL, Dunsomb JK, Harrison K, Heine PR, Stuanes A, Urrego B, Bonani G: Carbon cycling in a loblolly pine forest: Implications for the missing carbon sink and for the concept of soil. In Proceedings of the Eighth North American Forest Soils Conference on Carbon Forms and Functions in Forest Soil: May 1993; Gainesville, FL. Edited by: McFee WW, Kelly JM. Soil Science Society of America; 1995:233-251.

29. Rheinhardt RR, Brinson MM, Christian R, Miller KH, Meyer G: A referencedbased framework for evaluating the ecological condition of stream networks in small watersheds. Wetlands 2007, 27:534-542.

30. Megonigal JP, Conner WH, Kroeger S, Sharitz RR: Aboveground production in Southeastern floodplain: a test of the subsidy-stress hypothesis. Ecology 1997, 78:370-384.

doi:10.1186/1750-0680-7-4

Cite this article as: Rheinhardt et al:: Carbon storage of headwater riparian zones in an agricultural landscape. Carbon Balance and Management 2012 7:4. 